Urban History Review

Revue d'histoire urbaine

\title{
The Century Calgary Historical Series
}

Volume One. Past and Present: People, Places and Events in Calgary. Calgary: Century Calgary Publications, 1975. Pp. 391. Illustrations. $\$ 5.00$

Volume Two. Communities of Calgary: From Scattered Towns to a Major City. Calgary: Century Calgary Publications, 1975. Pp. 424. Illustrations. $\$ 5.00$

Volume Three. Young People of All Ages: Sports, Schools and Youth Groups in Calgary. Calgary: Century Calgary Publications, 1975. Pp. 496. Illustrations. \$5.00

Volume Four. The Search For Souls: Histories of Calgary's Churches. Calgary: Century Calgary Publications, 1975. Pp. 760. Illustrations. $\$ 5.00$

Volume Five. At Your Service, Part One: Calgary's Library, Parks Department, Military, Medical Services, and Fire Department. Calgary: Century Calgary Publications, 1975. Pp. 519. Illustrations. \$5.00

Volume Six. At Your Service, Part Two: Calgary's Police Force, Navy Base, Post Office, Transit System, and

Private Service Groups. Calgary: Century Calgary Publications, 1975. Pp. 576. Illustrations. $\$ 5.00$

Trudy Soby, A Walk Through Old Calgary: Early Buildings Extant in 1975. Calgary: Century Calgary

Publications, 1975. Pp. 46. \$2.75

Trudy Soby, Be It Ever So Humble: A Photoessay on Calgary's Old Homes. Calgary: Century Calgary

Publications, 1975. pp. 54. \$2.75

Max Foran

Numéro 2-76, october 1976

URI : https://id.erudit.org/iderudit/1019541ar

DOI : https://doi.org/10.7202/1019541ar

Aller au sommaire du numéro

Éditeur(s)

Urban History Review / Revue d'histoire urbaine

ISSN

0703-0428 (imprimé)

1918-5138 (numérique)

Découvrir la revue

Citer ce compte rendu

Foran, M. (1976). Compte rendu de [The Century Calgary Historical Series / Volume One. Past and Present: People, Places and Events in Calgary. Calgary: Century Calgary

Publications, 1975. Pp. 391. Illustrations. \$5.00 / Volume Two. Communities of Calgary: From Scattered Towns to a Major City. Calgary: Century Calgary Publications, 1975. Pp. 424. Illustrations. \$5.00 / Volume Three. Young People of All Ages: Sports, Schools and Youth Groups in Calgary. Calgary: Century Calgary Publications, 1975. Pp. 496. Illustrations. \$5.00 / Volume Four. The Search For Souls: Histories of Calgary's Churches. Calgary: Century Calgary Publications, 1975. Pp. 760. Illustrations. \$5.00 / Volume Five. At Your Service, Part One: Calgary's Library, Parks Department, Military, Medical Services, and Fire Department. Calgary: Century Calgary Publications, 1975. Pp. 519. Illustrations. $\$ 5.00$ / Volume Six. At Your Service, Part Two: Calgary's Police Force, Navy Base, Post Office, Transit System, and Private Service Groups. Calgary: Century Calgary Publications, 1975. Pp. 576. Illustrations. \$5.00 / Trudy Soby, A Walk Through Old Calgary: Early Buildings Extant in 1975. Calgary: Century Calgary Publications, 1975. Pp. 46. \$2.75 / Trudy Soby, Be It Ever So Humble: A Photoessay on Calgary's Old Homes. Calgary: Century Calgary Publications, 1975. pp. 54. \$2.75]. Urban History Review / Revue d'histoire urbaine, (2-76), 78-82. https://doi.org/10.7202/1019541ar

Ce document est protégé par la loi sur le droit d'auteur. L’utilisation des services d'Érudit (y compris la reproduction) est assujettie à sa politique d'utilisation que vous pouvez consulter en ligne.

https://apropos.erudit.org/fr/usagers/politique-dutilisation/ 
topics they had so interestingly raised.

Strangely enough, given the diversity of backgrounds represented by the authors there was little evidence of variety of methodology. Few charts were employed to demonstrate demographic growth; only a few pictures (and not particularly effective ones at that) were used to demonstrate changes in the built environment; and only three authors used tables to show shifts in population, economic development, and social patterns. Perhaps most surprisingly, there were no maps of the city itself; the absence or near-absence of such aids inevitably means that those unfamiliar with Calgary will lose the significance of much of the detail in the essays themselves.

Nevertheless, despite these limitations, Frontier Calgary is a delightful book that will be well received and usefully employed by both laymen and professional historians. Hopefully, it will encourage similar kinds of conferences in other cities and help bring together various local groups genuinely and enjoyably interested in understanding the history of their cities.

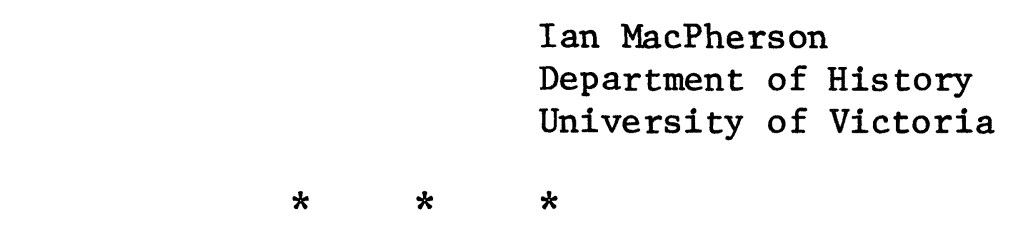

THE CENTURY CALGARY HISTORICAL SERIES

Volume One. Past and Present: People, Places and Events in Calgary. Calgary: Century Calgary Publications, 1975. Pp. 391. Illustrations. $\$ 5.00$.

Volume Two. Communities of Calgary: From Scattered Towns to a Major City. Calgary: Century Calgary Publications, 1975. Pp. 424. I1lustrations. $\$ 5.00$. 
Volume Three. Young People of A11 Ages: Sports, Schools and Youth Groups in Calgary. Calgary: Century Calgary Publications, 1975. Pp. 496. Illustrations. $\$ 5.00$.

Volume Four. The Search For Souls: Histories of Calgary's Churches. Calgary: Century Calgary Publications, 1975. Pp. 760. Illustrations. $\$ 5.00$.

Volume Five. At Your Service, Part One: Calgary's Library, Parks Department, Military, Medical Services, and Fire Department. Calgary: Century Calgary Publications, 1975. Pp. 519. I11ustrations. $\$ 5.00$.

Volume Six. At Your Service, Part Two: Calgary's Police Force, Navy Base, Post Office, Transit System, and Private Service Groups. Calgary: Century Calgary Publications, 1975. Pp. 576. Illustrations. $\$ 5.00$.

Photographic Collections:

Trudy Soby, A Walk Through 01d Calgary: Early Buildings Extant in 1975. Calgary: Century Calgary Publications, 1975. Pp. 46. \$2.75.

Trudy Soby, Be It Ever So Humble: A Photoessay on Calgary's '01d Homes. Calgary: Century Calgary Publications, 1975. pp. 54. \$2.75.

One of the many products of Calgary's 1975 centennial activities was the Century Calgary Historical Series. Prepared under the auspices of the Century Calgary Association, this six volume series plus two photograph collections represents a combined attempt by various authors to examine a wide range of topics relative to Calgary's history. The group of amateur historians who undertook this venture approached its task with enthusiastic abandon. The result is a series high in content matter but which suffers from severe organizational and methodo- 
logical deficiencies.

This is really not a six volume series but a collection of some thirty-two researched topics loosely grouped into broad categories and classified accordingly in volumes. Authors apparently were given little or no mandate regarding their choice of subject matter. As institutions provide the most identifiable frame of reference it is not surprising to find that no fewer than twenty-six studies are concerned with the growth and developments of organizations. Among the subjects treated are the police and fire departments; schools and churches; bands, scouts and guides; health and charitable organizations.

The institutional approach gives the series a very local character and provides a reader with a surfeit of chronology. Reminiscences are included and do provide some illuminating insights. It is unfortunate however, that such reminiscences were not used more purposefully. They appear more as aimless commentaries rather than observations directed at increasing a reader's awareness. Also as some of the studies concerned themselves with lengthy treatments of recent events, a good deal of factual information loses relevance from an historical point of view.

There appears to be an excessive amount of overlapping. This probably arises from the loosely structured approach taken by the authors, who appeared unaware of what was being done by their fellows. Certainly there seemed to be a lack of a general co-ordination which would have unified the series and avoided excessive repetitions. There are enough factual errors too to induce a wariness on the part of the historian seeking facts for documentation purposes. For example, C. C. King did not serve two terms as mayor; the C.P.R. shops were not built in 1898; 1886 did not mark the year of Calgary's first Town Council; and Blackfoot Treaty No. 7 was not signed in 1887. The almost total absence of footnotes or bibliography further reduces the validity of the series as a reference source for professional historians. 
The greatest disappointment of the series, from the reviewer's point of view, is its failure to examine sadly neglected areas in Calgary's history, while placing needless emphasis on others. For example some 300 pages were devoted to the Calgary Police Force in spite of the fact that the Force already has its own historian - albeit unofficial - who is currently preparing his own history of the Force. Virtually nothing appears in the series on ethnic groups. Very little documentation exists on ethnic groups in Calgary, and it seems remiss that some effort was not made to record the reminiscences of those long time residents who could have made worthwhile contributions. The series lends itself admirably to the interview approach, while the information so collated would have proven invaluable to students of Calgary history. Some other needed areas that were not dealt with were biographies of local businesses and their owners; street railway development; the growth of Ogden, the C.P.R. Suburb; labour organizations and real estate speculation.

The series is, in the main, quite readable and doubtless will provide hours of pleasant entertainment for those wishing to acquaint themselves with aspects of Calgary's institutional - and social-development. The pages of text are liberally interspersed with some excellent photographs which add to the series' appeal. Of specific interest are the two photograph collections. A Walk Through 01d Calgary is particularly valuable and can be utilized in a practical situation to acquaint students with the exact location of Calgary's early business centre. The commentaries in this volume and its companion on early residences and public buildings are most informative and should provide readers, teachers and students with plethora of factual data.

There are areas in the series which will prove valuable for academic research purposes. Many of the leading businessmen and politicians in Calgary were deeply involved in charitable work. Such involvement does not always reflect itself in the personal papers of these men. Yet many references to their roles in societies are contained 
in the volumes which deal with youth and service organizations (Vols. III, V, and VI). Although Calgary mayors are given but cursory treatment there is a valuable biographical sketch on one of the lesser known mayors, Sam Adams. The writer appeared to have had personal acquaintance with Adams and as a result his sketch provides some illuminating insight into personality and policy. At the conclusion of the last section on the police force is a synopsis by years of pertinent statistical data. Such will provide a quick and ready reference for interested students. Bowness community is the subject of a whole section in Volume II. The development of Bowness was particularly interesting as it combined those elements of land speculation and street railway services to influence strongly the direction of Calgary's physical growth. Information contained in this section provides some personal insights which shed light on the improbable nature of the whole Bowness project.

This is essentially a series for popular consumption. It represents more a labor of love and personal commitment than it does a serious contribution to Western Canadian Historiography. The basic value from a purely historical point of view is as a reference source for elaborative data on individuals and organizations. Even then such information cannot readily be located and often appears in most unlikely places. The Century Calgary Society is to be commended for its initiative in undertaking such a project. It is unfortunate, however, that the directors of the project being blessed as they were with financial and willing human resources could not have unified their efforts to ascertain needed priorities before beginning their endeavour. Had they done so they would doubtless have made a more valuable contribution to Calgary's history than that represented by their present series. 